\title{
Natural History of Ghate's Shrub Frog, Raorchestes ghatei (Rhacophoridae), from the Northern Western Ghats, India
}

\author{
Amit Sayyed and Anand Padhye
}

Wildlife Protection and Research Society, 40 Rajaspura peth Satara, Maharashtra, India (amitsayyedsatara@gmail.com)

Photographs by the senior author

$A^{\text {ntin }}$ mphibians employ a remarkable diversity of reproductive strategies (Crump 2010) exhibiting as many as 40 different methods (Gururaja 2010). Reproductive modes are classified based on egg deposition sites, egg type, and patterns of embryonic development (Wells 2007), but classification is difficult and often arbitrary (Lehtinen and Nussbaum 2003). Most anuran reproduction involves aquatic larval stages, but direct development is not uncommon (Stuart et al. 2008). Parental care increases offspring survivorship in species (Trivers 1972) and parental behaviors are highly responsive to changes in the environment (Royle et al. 2014; Seshadri and Bickford 2018). Parental care is uncommon in frogs, Günther's Bush Frog (Raorchestes chalazodes, Rhacophoridae) is the only species in the genus in which parental care has been reported, with males attending eggs to protect them from conspecific males (Seshadri and Bickford 2018).

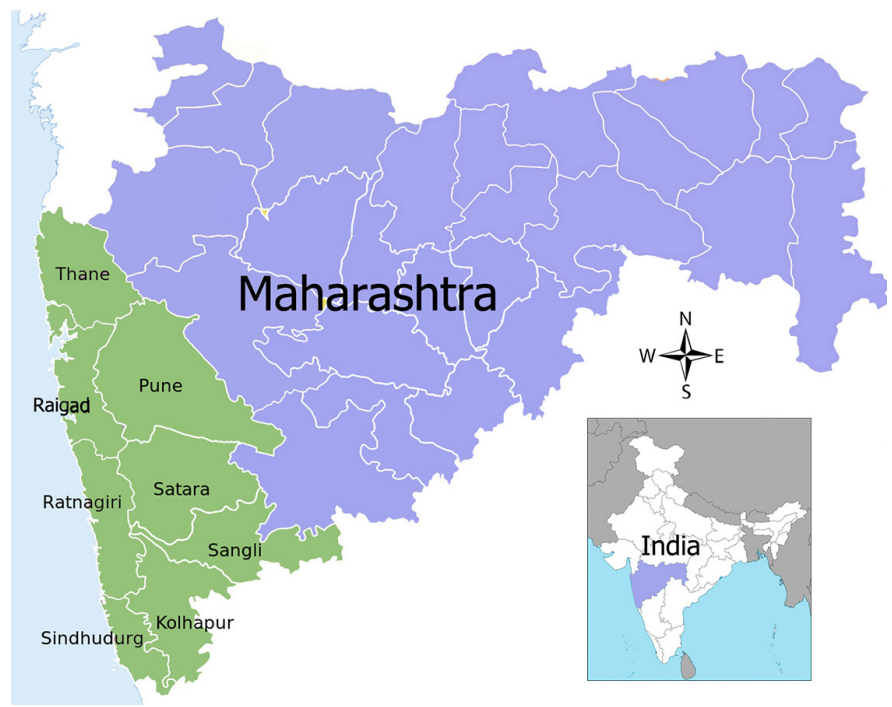

Fig. 1. The districts (green) of Maharashtra, India, where Ghate's Shrub Frog (Raorchestes ghatei) is known to occur.
Rhacophorids employ a variety of reproductive modes, with reproduction in the genus Raorchestes characterized by direct development. Ghate's Shrub Frog (Raorchestes ghatei) is a recently described species from the northern Western Ghats (Padhye et al. 2013), currently known only from the type locality and nearby areas (Fig. 1). Herein we describe the breeding biology and natural history of this little-known species.

\section{Methods}

We observed Raorchestes ghatei at the type locality of Chalkewadi $\left(17.59^{\circ} \mathrm{N}, 73.84^{\circ} \mathrm{E}\right.$; elevation $\left.1,082 \mathrm{~m}\right)$, Satara, Maharashtra, India in June to October 2013 with breeding during August. We used a Yamayo Digimatic Caliper (Yamayo India, Mumbai, India) for morphometric measurements to the nearest $0.1 \mathrm{~mm}$; a PL83-S Mettler Portable Balance (Mettler-Toledo, Columbus, Ohio, USA) for weights to the nearest $0.001 \mathrm{~g}$; an Infrared Thermometer TES1326 (TES Electrical Electronic Corporation, Taipei, Taiwan, ROC) for temperatures of frogs, soil at egg-laying sites, and water in the adjacent stream to the nearest $0.01{ }^{\circ} \mathrm{C}$; and a Mini Environmental Quality Meter 850070 (Sper Scientific, Scottsdale, Arizona, USA) for atmospheric temperatures and relative humidity.

\section{Results and Discussion}

Raorchestes ghatei occurs on plateaus, slopes with shrubby vegetation, and in densely forested areas as well as vegetation near human habitation. Peak activity of adults begins with the first rains in early June and continues through the rainy season into October. Males call from trees and bushes, usually beginning around $1800 \mathrm{~h}$ but sometimes earlier, and continuing past midnight and often throughout the night. However, some males will call during the day, especially during light rain. Calling often ceases during heavy rainfall. From 

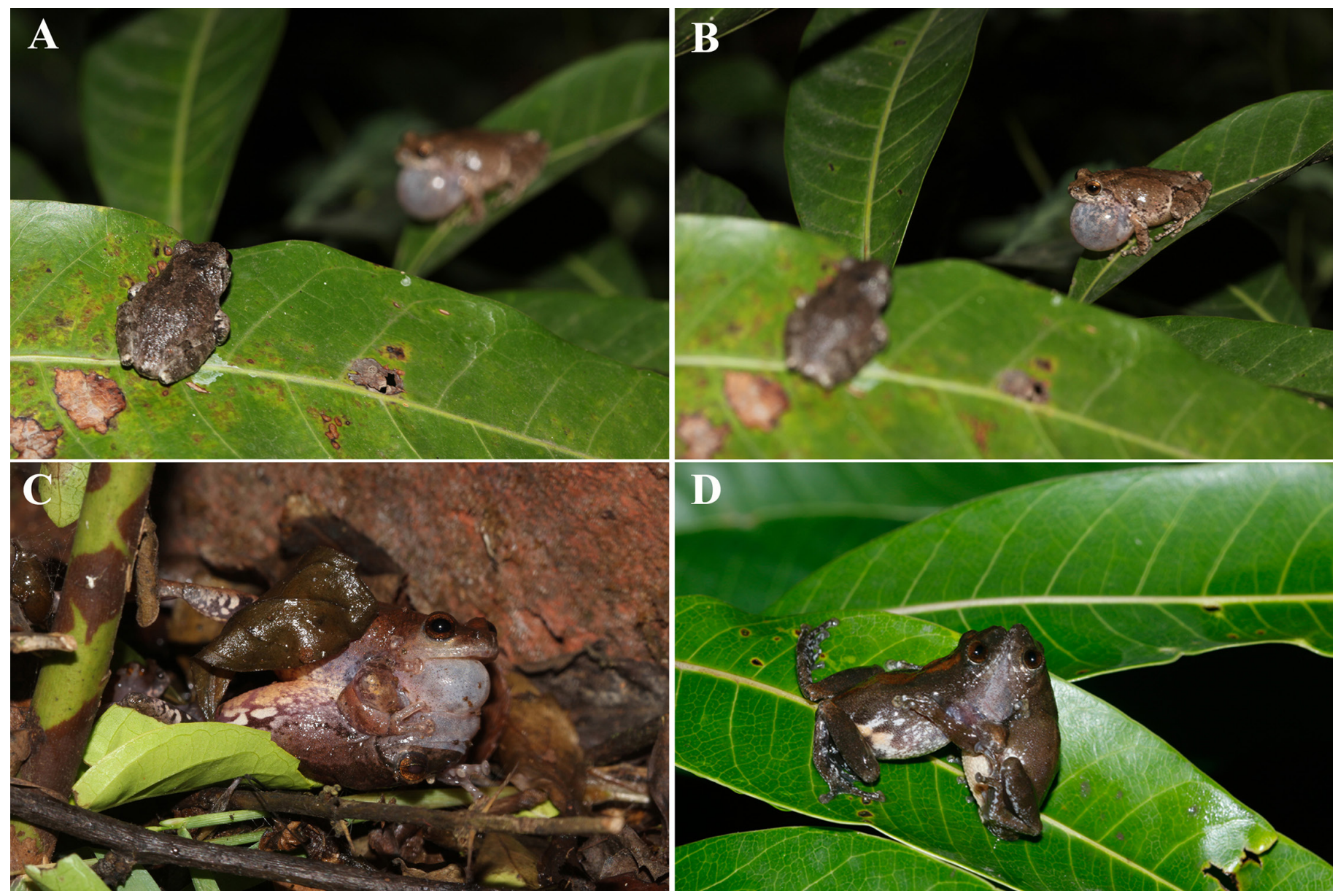

Fig. 2. Territorial behavior of Ghate's Shrub Frog (Raorchestes ghatei): Vocalization (A \& B) and combat on the ground (C) and on the leaf of a tree (D).

the first showers in June until August, males generally call from low perches close to the ground, where females occur in large numbers. Later in the season, males call from shrubs or trees at heights of 3-5 m. Calling males are territorial, using distinct territorial calls in addition to mating calls to define a territory. They also will resort to fighting to defend territories (Fig. 2), occasionally throwing the loser from the elevated perch. Males that lose vocal interactions or fights sometimes cease calling and remain silent within the territory of a dominant male.

Females were usually on the ground (Fig. 3A). When a female approached a bush with a male emitting the most frequent and loudest calls (Fig. 3B), she climbed the bush (Fig. $3 \mathrm{C}$ ), approached the male, who mounted her and engaged in axillary amplexus (Fig. 3D). The amplecting pair then descended to the ground and searched for stones (Fig. 3E), beneath which eggs usually are laid. However, if a pair does not find a suitable stone, ovideposition takes place in wet leaf litter on the forest floor (Fig. 3F).

Clutch size is between 40 and 60 eggs (Fig. 4; Table 1). After ovideposition, the male climbs the original bush, assumes the calling position, and starts calling. The female usually leaves the clutch. However, after the monsoon, we found females guarding eggs under the stone where they were laid. We never encountered this during heavy rains and assume that their presence near eggs after the monsoon is to keep the eggs moist with water or urine (Fig. 5A). If disturbed, a female shows aggressive behavior by elevating her body toward the threat (Fig. 5B), clearly demonstrating that females are protecting their fertilized eggs from potential predators and also maintaining sufficient moisture to assure hatching in less than ideal conditions. In the absence of an attending female, we observed eggs parasitized by insects and subjected to fungal infections.

During this period, we collected and measured a few individuals (Table 2). Females were larger than males. Snoutvent lengths (SVL) of adult males were $21.33-21.93 \mathrm{~mm}$ and those of females 25.16-29.69 mm. Padhye et al. (2013) had listed sizes of males as 19.1-25.5 mm and those of females as $15.4-29.8 \mathrm{~mm}$. Weights of males, including subadults, were $0.763-1.089 \mathrm{~g}$, whereas non-gravid adult females weighed $1.124-1.128 \mathrm{~g}$ and gravid females $1.131-1.137 \mathrm{~g}$. The abdomens of non-gravid females measured 15.19-15.78 $\mathrm{mm}$, whereas those of gravid females measured 18.82-19.28 $\mathrm{mm}$. Body temperatures of all frogs were $17.05-17.09^{\circ} \mathrm{C}$. Temperatures at which eggs developed were $20-22^{\circ} \mathrm{C}$, soil 

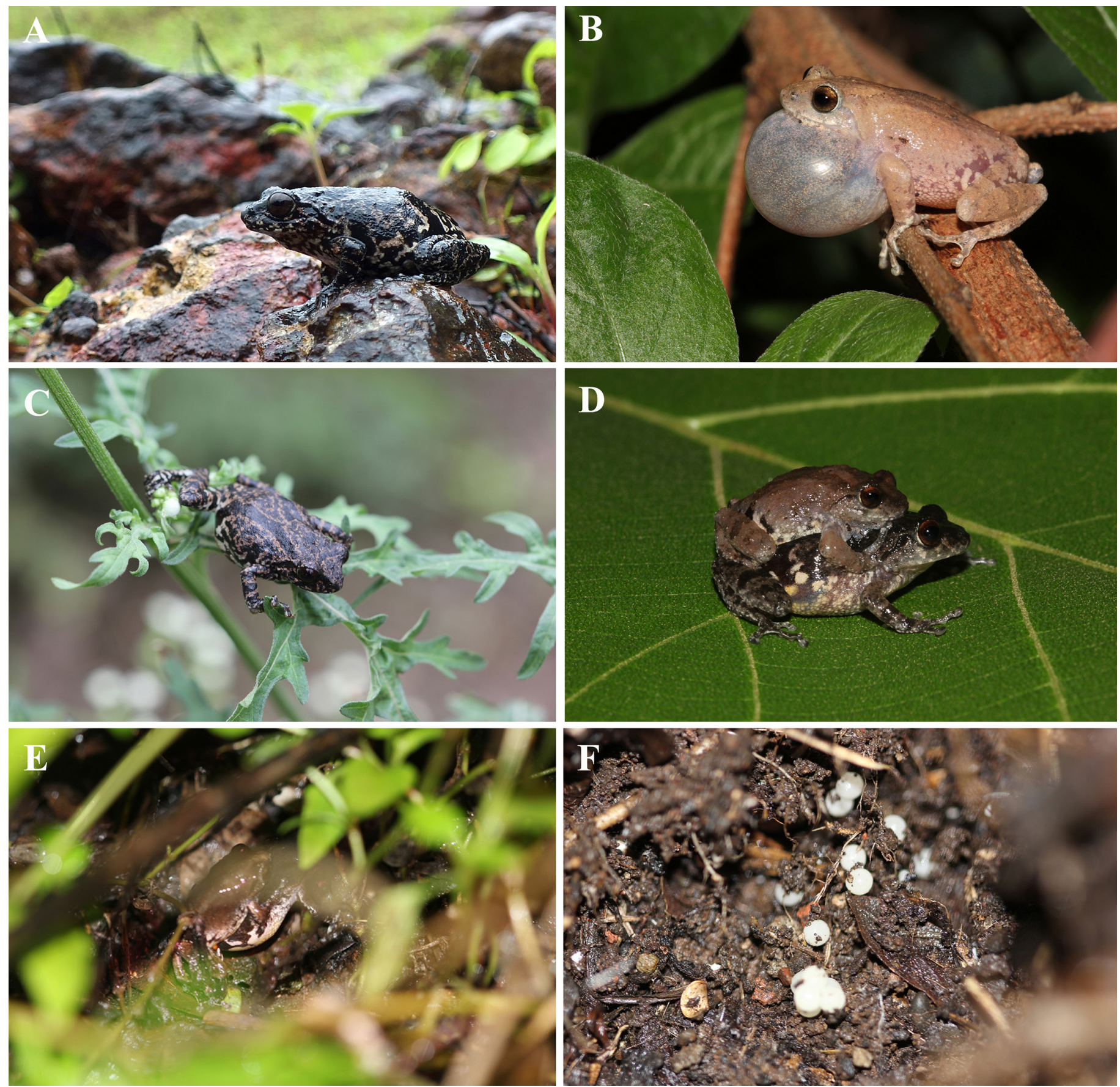

Fig. 3. Reproduction in Ghate's Shrub Frog (Raorchestes ghatei): Gravid female (A), calling male (B), female approaching male (C), amplexus (D), amplecting pair searching for an appropriate place to lay eggs (E), and eggs (F).

temperatures where clutches were found were 18.07-19.05 ${ }^{\circ} \mathrm{C}$, and water temperatures near the egg-laying sites were $20.00-20.05^{\circ} \mathrm{C}$. The average diameter of eggs in the three clutches for which data are available was $2.49-2.53 \mathrm{~mm}$. Time required to complete development varied from 21 to 30 days depending on local conditions (Fig. 6; Table 1). Heart rates of froglets were 89-93 beats per minute on day 20. Hatchling frogs in each clutch all emerged within 24-48 h.

We selected one clutch to observe changes in egg diameter and development (Table 3). The outer egg membranes became increasingly thin and transparent. Eyes of the larvae were initially lateral but migrated dorsally during development of the limbs. Once tails are resorbed, hatchlings are ready to emerge (Fig. 7). Adult frogs were less frequently encountered in September and October when recent hatchlings are abundant. Calling decreased noticeably in December.

Prey of adult frogs included crickets (adults and nymphs), grasshoppers, other small insects, and small spiders. Hatchlings fed on mosquitoes and other small insects. We observed the Saw-scaled Viper (Echis carinatus), Bamboo 


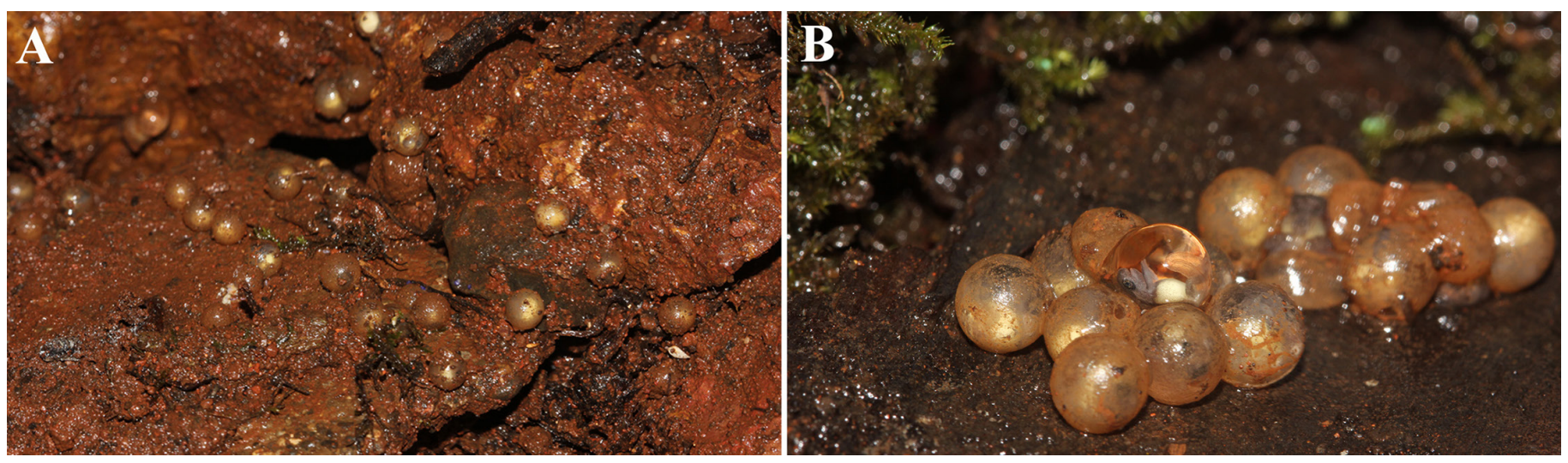

Fig. 4. Two egg clutches of Ghate's Shrub Frog (Raorchestes ghatei).

Table 1. Data from three egg clutches of Ghate's Shrub Frog (Raorchestes ghatei) at Chalkewadi, Satara.

\begin{tabular}{lccccc} 
Date of Oviposition & Site & Clutch Size & Egg Diameter $(\mathbf{m m})$ & Date of Hatching & Duration \\
\hline 21 July 2013 & under a stone & 59 & $2.50-2.53$ & $16-18$ August 2013 & 29 days \\
\hline 27 July 2013 & leaf litter & 43 & $2.49-2.54$ & $18-20$ August 2013 & 25 days \\
\hline 07 August 2013 & under a stone & 54 & $2.49-2.52$ & $27-28$ August 2013 & 21 days \\
\hline
\end{tabular}
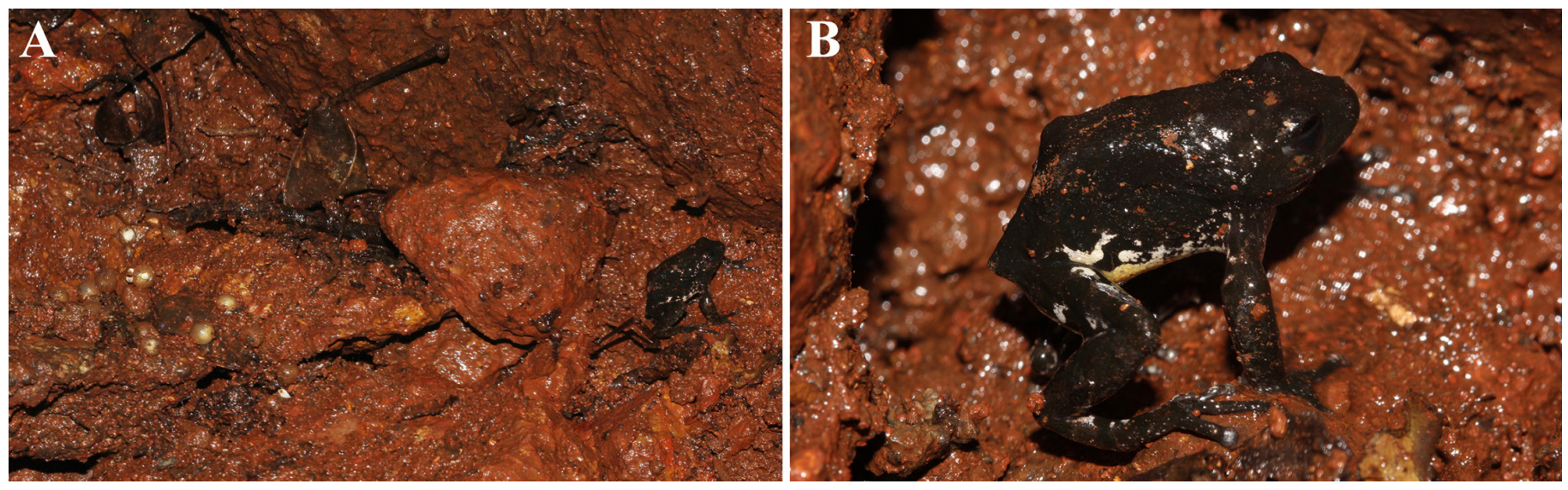

Fig. 5. Female Ghate's Shrub Frog (Raorchestes ghatei) protecting her eggs.

Table 2. Morphometric data for Ghate's Shrub Frog (Raorchestes ghatei) at Chalkewadi, Satara. SVL = snout-vent length. Dashes indicate not-applicable information.

\begin{tabular}{|c|c|c|c|c|c|c|}
\hline Sex & Remarks & $\begin{array}{l}\text { SVL } \\
(\mathrm{mm})\end{array}$ & $\begin{array}{l}\text { Weight } \\
(\mathrm{g})\end{array}$ & $\begin{array}{c}\text { Temperature } \\
\left({ }^{\circ} \mathrm{C}\right)\end{array}$ & $\begin{array}{l}\text { Abdominal Girth (mm) } \\
\text { Before Oviposition }\end{array}$ & After Oviposition \\
\hline $\bar{M}$ & - & 21.88 & 1.081 & 17.09 & - & - \\
\hline $\mathrm{M}$ & subadult & 18.71 & 0.763 & 17.08 & - & - \\
\hline $\mathrm{M}$ & - & 20.68 & 0.869 & 17.07 & - & - \\
\hline $\mathrm{F}$ & gravid & 25.66 & 1.131 & 17.09 & 18.82 & 15.34 \\
\hline $\mathrm{F}$ & gravid & 29.69 & 1.137 & 17.08 & 19.28 & 15.78 \\
\hline $\mathrm{F}$ & gravid & 27.36 & 1.134 & 17.09 & 19.13 & 15.46 \\
\hline $\bar{F}$ & non-gravid & 25.16 & 1.124 & 17.09 & - & 15.19 \\
\hline
\end{tabular}




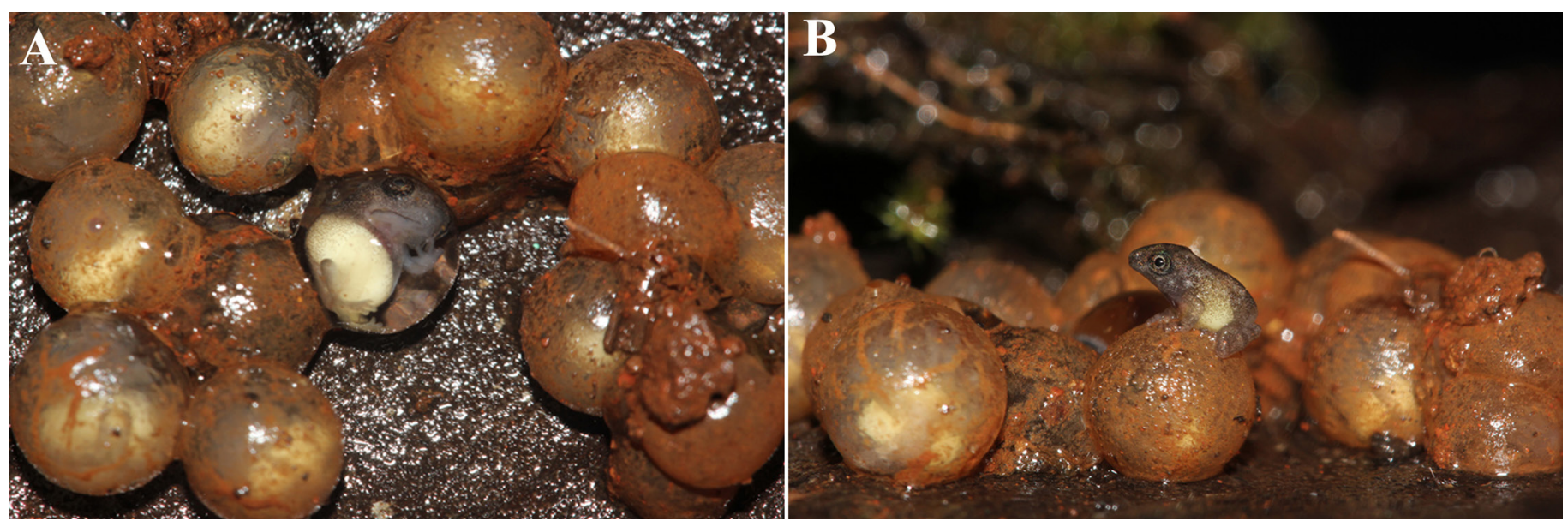

Fig. 6. Development of Ghate's Shrub Frog: Larvae in eggs (A) and an emergent froglet (B).

Table 3. Ghate's Shrub Frog (Raorchestes ghatei) eggs and hatchlings in one clutch at Chalkewadi, Satara. All measurements in mm.

\begin{tabular}{lcccccc} 
Date & Day & Egg 1 & Egg 2 & Egg 3 & Egg 4 & Egg 5 \\
\hline 07 August 2013 & 1 & 2.50 & 2.49 & 2.50 & 2.52 & 2.50 \\
\hline 08 August 2013 & 2 & 3.20 & 3.20 & 3.20 & 3.21 & 3.20 \\
\hline 12 August 2013 & 6 & 3.41 & 3.40 & 3.41 & 3.43 & 3.41 \\
\hline 15 August 2013 & 9 & 3.67 & 3.65 & 3.66 & 3.67 & 3.66 \\
\hline 17 August 2013 & 11 & 3.90 & 3.89 & 3.89 & 3.91 & 3.90 \\
\hline 20 August 2013 & 14 & 4.28 & 4.26 & 4.28 & 4.29 & 4.26 \\
\hline 23 August 2013 & 17 & 4.42 & 4.40 & 4.41 & 4.43 & 4.42 \\
\hline 25 August 2013 & 19 & 4.58 & 4.56 & 4.57 & 4.60 & 4.58 \\
\hline 28 August 2013 & 22 & 4.71 & 4.69 & 4.72 & 4.74 & 4.72 \\
\hline
\end{tabular}

Hatchling SVL

\begin{tabular}{llllll}
\hline 28 August 2013 & 4.27 & 4.21 & 4.35 & 4.47 & 4.33 \\
\hline
\end{tabular}
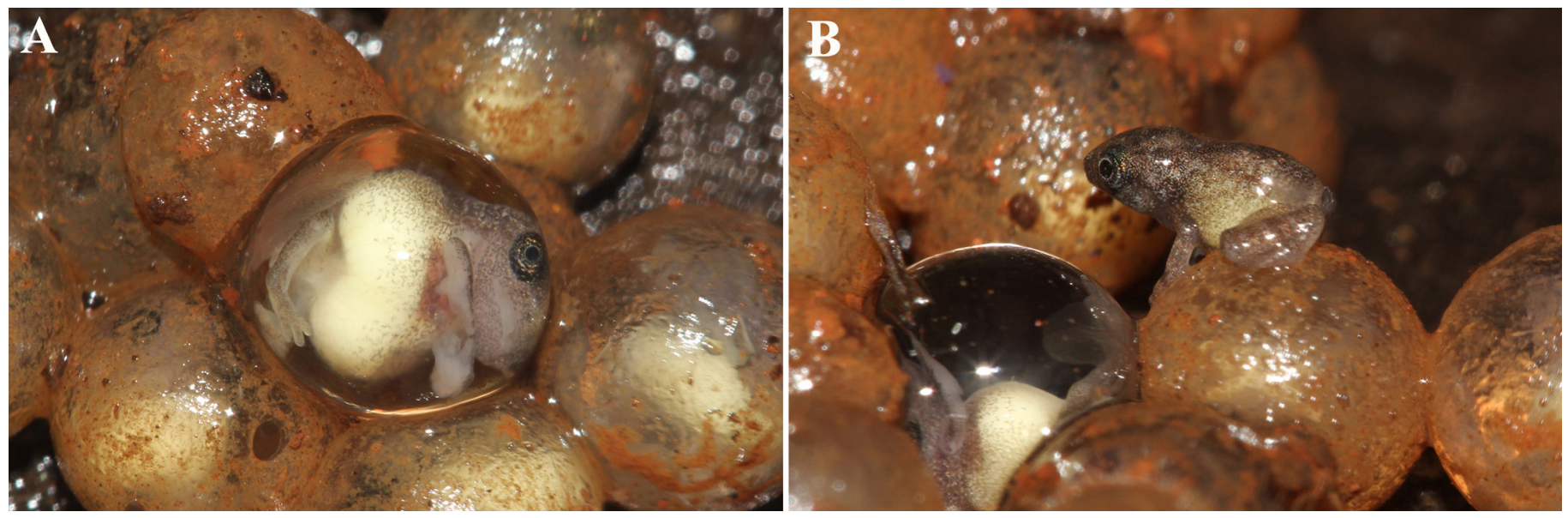

Fig. 7. Development of Ghate's Shrub Frog: Limb formation and degenerating tail (A) and an emergent froglet (B). 

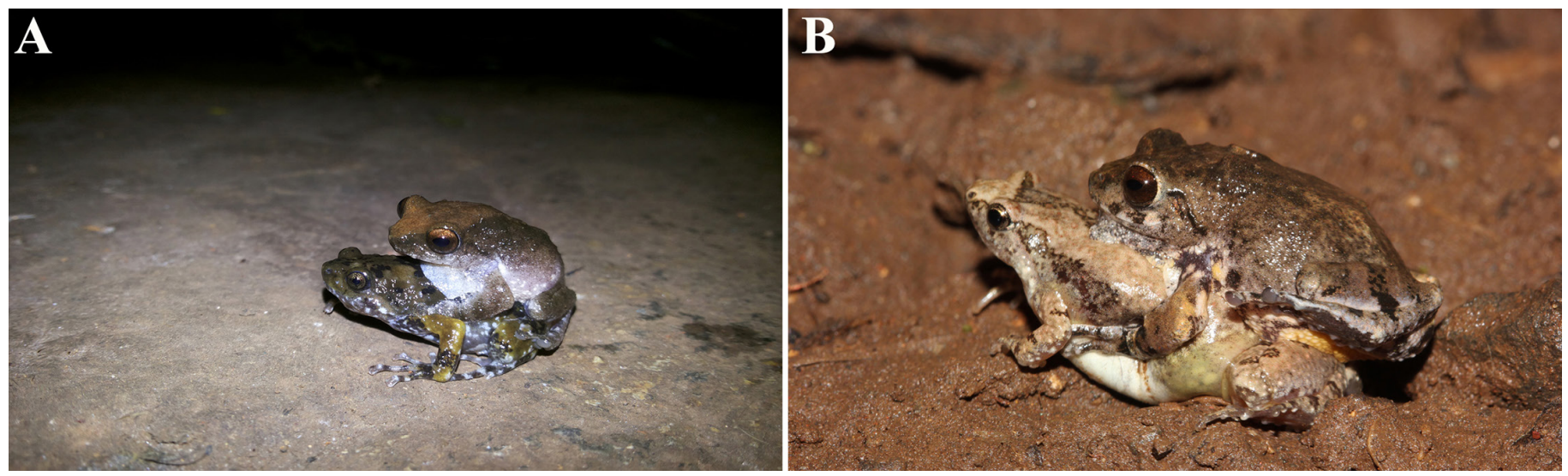

Fig. 8. Interspecific amplexus: Male Ghate's Shrub Frogs (Raorchestes ghatei) in amplexus with a female Mottled Globular Frog (Uperodon mormoratus; Microhylidae) (A) and with a gravid female Ornate Narrow-mouthed Frog (Microhyla ornata; Microhylidae) (B); note the eggs visible in the abdomen of the latter.

Pitviper (Trimeresurus gramineus), Changeable Lizard (Calotes cf. versicolor), Forest Lizard (Calotes nigrilabris), and White-throated Kingfisher (Halcyon smyrnensis) preying on R. ghatei.

Interspecific amplexus has been reported in the family Rhacophoridae (Sayyed 2013; Sayyed and Nale 2017), and Yadav and Yankanchi (2014) reported intergeneric amplexus between a Maharashtra Bush Frog (Raorchestes bombayensis) and an Ornate Narrow-mouthed Frog (Microhyla ornata). On 2 October 2015 at Ragnafort, Kolhapur, Abhijit Nale and Devendra Bhosle (Wildlife Protection and Research Society members) observed interspecific amplexus between Raorchestes ghatei and a Mottled Globular Frog (Uperodon mormorata) (Fig. 8A) and, on 8 November 2015, the senior author encountered a male $R$. ghatei in amplexus with a gravid female Microhyla ornata, (Fig. 8B) at Parli, Satara. Interspecific amplexus is most commonly seen in explosive breeders; in some toads (Bufonidae), individuals do not always distinguish the sex of conspecifics and interspecific amplexus between congeners and even confamilial species is a relatively common event (Wells 2007). Contributing factors could include stress triggered by competition for breeding sites or even a disproportionate number of females at some locations (e.g., Machado and Bernarde 2011; Sayyed and Nale 2017).

\section{Literature Cited}

Crump, M.L. 2010. Amphibian diversity and life history, pp. 1-19. In: K.C. Dodd, Jr. (ed.), Amphibian Ecology and Conservation. A Handbook of Techniques. Oxford University Press, Oxford, UK.

Gururaja, K.V. 2010. Novel reproductive mode in a torrent frog Micrixalus saxicola (Jerdon) from the Western Ghats, India. Zootaxa 2642: 45-52.

Lehtinen, R.M. and R.A. Nussbaum. 2003. Parental care: A phylogenetic perspective, pp. 343-386. In: B.G.M. Jamieson (ed.), Reproductive Biology and Phylogeny of Anura. Volume 2 of Series: Reproductive Biology and Phylogegy. Science Publishers Inc., Enfield, New Hampshire.

Machado, R.A. and P.S. Bernarde. 2011. Multiple and heterospecific amplexi between the toads Rhaebo guttatus and Rhinella marina (Anura: Bufonidae). Herpetology Notes 4: 167-169.

Padhye, A.D., A. Sayyed, A. Jadhav, and N. Dahanukar. 2013. Raorchestes ghatei, a new species of shrub frog (Anura: Rhacophoridae) from the Western Ghats of Maharashtra, India. Journal of Threatened Taxa 5: 4913-4931.

Sayyed, A. 2013. Note on the natural crossbreeding in Family Rhacophoridae, Anura, Amphibia. Ela Journal 2(3): 7-9.

Sayyed, A. and A. Nale. 2017. New distribution record and intergeneric amplexus in the Malabar Tree Toad, Pedostibes tuberculosus Günther 1875 (Amphibia: Anura: Bufonidae). Reptiles \& Amphibians 24: 193-196.

Seshadri, K.S. and D.P. Bickford. 2018. Faithful fathers and crooked cannibals: The adaptive significance of parental care in the bush frog Raorchestes chalazodes, Western Ghats, India. Behavioral Ecology and Sociobiology 72: 4 (DOI: 10.1007/s00265-017-2420-3).

Trivers, R.L. 1972. Parental investment and sexual selection, pp. 136-179. In: B. Campbell (ed.), Sexual Selection and the Descent of Man. Aldine Publishing Co., Chicago, Illinois, USA.

Wells, K.D. 2007. The Ecology and Behavior of Amphibians. The University of Chicago Press, Chicago, Illinois.

Yadav, O. and S.R. Yankanchi. 2014. Raorchestes bombayensis (Bombay Bush Frog) and Microhyla ornata (Ornate Narrow Mouthed Frog). Interspecies amplexus. Herpetological Review 45: 683. 